\title{
ДИПЛОМАТІЯ ЄВРОПЕЙСЬКОГО СОЮЗУ ТА ЕКО-БРЕНДИНГ КРӒ̈Н
}

\author{
A.В. Бохан \\ кандидат економічних наук, доцент \\ Київський національний торговельно-економічний університет \\ (Україна, м. Київ, e-mail: alina.bokhan@i.ua)
}

У статті розглянуто питання розвитку дипломатї Європейсъкого Союзу, їі ролі в міжнародній інтеграції та бормування еко-брендингу країн. Визначено головні чинники активізачї дипломатичної діяльності в умовах глобалізачї та загострення екологічних проблем. Актуалънил є бормування нового іміджу СС та утвердження екологічних імперативів у міжнародних економічних, ділових та культурних комунікаиіях. Синхронізаиія дій країн у иій сбері передбачає досягнення иілей розвитку за проектом міжнародної співпрачі «The 2030 Agenda for Sustainable Development». Результати країн у досягненні иілей впливають на ї міжнародний образ /імідж у світі.

В умовах загострення конкурениї сприйняття країн ЄС борлуєтъся на основі активної дипломатії політиків, знаних діячів, підприємиів. Міжкультурні комунікації стимулюють міжнародний діалог $і$ взаєморозуміння. Дипломатичні ініиіативи у бормуванні брендингу країни спрямовано на: еббективні зв'язки з іншими країнами (економічні, ділові, комериійні, торговелъні); використання "м'якої сили» впливу через культурну, релігійну, туристичну, рекреаиійну, екологічну та іншу привабливість; бормування сприятливих умов взаємодї різних країн (міжнародний бізнес, інвестиційний клімат, інновачійна мережа); представлення національної продукцї на світових ринках (товарний бренд, корпоративний бренд, бірмовий бренд); персональний бренд (президент, політик, дипломат, бізнеслен) для забезпечення конструктивності діалогу, перегорів, медіації.

Імідж ЄС та ї̈ дипломатичної служби обумовлено характером зовнішніх зносин на боні багатополярної системи міжнародних економічних відносин інеобхідністю використання колективних ресурсів. Дипломатія ЄС у рамках потужної інтеграційної спілъноти успішно бормує еко-брендинг. Надалі ие має забезпечити: удосконалення екологічної політики; збалансування ресурсних можливостей і потреб суспільства; узгодення цүілей торговельної та екологічної політики країн; бормування нових ринків екологічної продукиї та інвестування екологічно спрямованих проектів. За показниками Індексу екологічної ебективності країни лідерами СС є Франиія, Данія, Мальта, Швеція, Великобританія, Австрія, Ірландія, Фінляндія. У перспективі розвиток міжнародного діалогу є одним із ключових напрямів співпраці України та ЄС у рамках Угоди про асоиіаијію між Україною $i$ СС - ие собера охорони навколишнъого природного середовища.

Ключові слова: європейсъка дипломатія, еко-бренд, міжнародна екологічна політика, екологічна дипломатія, глобалізаијія.

Постановка проблеми. Глобальні процеси впливають на зміну простору життєдіяльності людства, обумовлюючи тренди в міжнародних економічних відносинах і необхідність реагування на них у багатовимірних контекстах. Підгрунтям для цього слугує міжнародна інтеграція, що оновлює стратегічні орієнтири країни у сорері політики, економіки, екології. Це змінює форми конкуренції та співробітництва, ефрективність соціально-економічного розвитку та науково-технічного прогресу на основі позицій країн у їх спроможності формувати не лише власне благополуччя, але й спільно брати участь у розв'язанні екологічних проблем.

У цьому аспекті роль держави зростає через реалізацію екологічної політики засобами дипломатії. Значний інтерес проявляється саме до тих країн, які мають певний досвід у підтриманні образу «могутніх», «успішних» i «лідерських». Забезпечення країнами такої статусності має свої особливості, що залежить від їх спроможності виступати єдиним інтеграційним фрронтом з іншими країнами в представленні та захисті спільних інтересів на міжнародній арені. Свропейський Союз демонструє серйозність намірів у формуванні нового рівня дипломатії, орієнтованої на перетворення викликів глобалізації на нові можливості суспільного розвитку.

Особливого значення у цих процесах набувають питання формування статусних позицій та іміджу ЄС через утвердження екологічних імперативів у міжнародних економічних, ділових та культурних комунікаціях. На порядку денному - синхронізація дій країн у відповідності до загальносвітових тенденцій, які ще у 2000 р. були ознаменовані прийняттям «Декларації тисячоліття ООН» та окресленням міжнародних цілей розвитку «Millennium Development Goals». Генеральна Асамблея $\mathrm{OOH}$ 
підвела підсумки виконання поставлених цілей у 2015 р. і прийняла резолюцію щодо нового проекту міжнародної співпраці «The 2030 Agenda for Sustainable Development». У ньому окреслено 17 цілей: ліквідація бідності та голоду; міцне здоров'я і благополуччя; якісна освіта; гендерна рівність; чиста вода і санітарія; чиста енергія; достойна робота та економічне зростання; індустріалізація, інновації, інфрраструктура; зменшення нерівності; збалансовані міста; відповідальне споживання і виробництво; боротьба зі зміною клімату; збереження морських екосистем; збереження екосистем суші; мир, правосуддя і ефрективні інститути; партнерство в інтересах стійкого розвитку. Очевидним є те, що результативність країн у досягненні таких цілей може впливати на їх міжнародний образ/бренд у світі.

Аналіз останніх досліджень і публікацій. Наукові дослідження питання брендингу країн розглядаються вченими в аспекті різної проблематики: імідж країни, національний бренд, «зелений» бренд. Про це йдеться у низці наукових праць дослідників: вітчизняних (Д. Кіслов, Т. Циганкова, Т. Завгородня, Г. Полішко) і зарубіжних (Д. Аккер, С. Ангольт, Й. Фан) [1-6]. Науковці наполягають на тому, що брендинг країни - це систематичний і комплексний процес узгодження ринкових дій, політичних зусиль, стратегічних намірів, залучення інвестицій та інновацій, налагодження міжнародних комунікацій для фрормування асоціативної моделі позитивного сприйняття країни.

Виділення невирішених раніше частин загальної проблеми. Дослідження з вказаної тематики є, здебільшого, міждисциплінарними та спонукають до виявлення взаємозв'язків щодо міжнародного позиціонування країн і державотворення. Разом з тим процес здобуття лідерства країн ЄС у конкурентному середовищі відбувається за активної дипломатії з боку державних діячів та інституцій, політиків, дипломатів, підприємців. Це також має спонукати дієвих, ринкових і соціальновідповідальних суб'єктів привносити нові ракурси у формування конструкту брендингу країни через оновлення його змісту, в якому екологічний аспект наразі ще не набув необхідного відображення у сорері внутрішньої та зовнішньої політики, дипломатичної служби, державного управління, національного та міжнародного бізнесу тощо.

Метою дослідження є визначення сучасних тенденцій у розвитку дипломатії СС з урахуванням необхідності фрормування, представлення та захисту на світових ринках екологічного брендингу країн в умовах глобалізації.
Матеріали та методи. Відповідно до мети дослідження, в статті застосовано методи аналізу та синтезу, що забезпечують відповідну логіку розкриття особливостей дипломатичної діяльності, а також виявляють її фрункціональну специфіку в контексті зростання уваги до екобрендингу країн. Загальнонаукові та спеціальні методи дають змогу окреслити нові завдання європейської дипломатії з огляду на розширення напрямів діяльності на основі стратегій екологічного розвитку. Інформаційною базою наукової розвідки з проблематики слугує аналіз праць вітчизняних і зарубіжних вчених.

Викладення основного матеріалу дослідження. Глобальний простір економічних взаємодій сприяє фрормуванню нових можливостей досягнення ринкового успіху i, водночас, швидкості зміни критеріїв оцінки його перспектив. Саме прагнення до налагодження міжкультурних комунікацій фрормує атмосореру розвитку міжнародного діалогу та взаєморозуміння. Вважається, що багата культура деяких країн є джерелом їх економічного успіху та процвітання, а відомі особистості та видатні діячі — можуть бути послами доброї волі. Всі країни світу можуть сприйматися через призму їх внеску в цивілізаційний розвиток, фрормування миру та політики добросусідства, збереження природно-культурної спадщини, забезпечення функціонування та урізноманітнення світового господарства, а також підтримання екологічної рівноваги для стійкості життєзабезпечення та безпеки існування людства.

У наш час — індустріалізованої й інформатизованої епохи - спільноти демонструють потребу в генеруванні нових ідей, концептів, технологій і новацій, що у підсумку змінюють фрілософрію сприйняття «образу» як самої людини, так і фрірми, компанії, продукту, товарів, послуг з метою підсилення їх споживчих/конкурентних переваг. Особливе місце у цій системі координат відводиться «образу» країни, який має всі шанси бути не лише комплексно презентований для кращого його сприйняття різними спільнотами, але й оцінений/виміряний у грошовому еквіваленті як міжнародний бренд. 3 метою його фрормування, стимулювання, підтримання та розвитку використовується низка інструментів, серед яких найбільш універсальний — це дипломатія.

Так, міжнародна політика задіяння сил дипломатичної підтримки у формуванні брендингу країни може бути реалізована на основі різних акцій, дій, заходів, програм і проектів у вигляді:

- спроможності до налагодження ефективних зв'язків з іншими країнами (економічних, ділових, комерційних, торговельних тощо); 
- презентованості країн на основі прояву ними «м'якої сили» впливу через культурну, релігійну, туристичну, рекреаційну, екологічну тощо привабливість;

- комфрортності взаємодії з суб'єктами ринку інших країн (ведення міжнародного бізнесу, інвестиційний та інноваційний клімат);

- представленості національної продукції на світових ринках через товарний бренд, корпоративний бренд, фрірмовий бренд тощо;

- значущості персонального брендингу (президента, політика, дипломата, бізнесмена, фінансиста, громадських діячів) у процесі налагодження міжнародного діалогу, перегорів, медіації тощо.

Доцільно зауважити, що сучасний науковий концепт «брендинг країни» є змістовним за елементами його наповнення, але має очевидну складність у практичній апробації і тому передбачає обов'язковість використання різних інструментів, фрорм і моделей дипломатії.

Свідченням цього є розвиток дипломатії ЄC, що демонструє фракти поступу, здобутків і труднощів у царині міжнародної діяльності. Слід наголосити, що на сучасному етапі європейської інтеграції сорормувалися виклики для традиційної дипломатії на трьох рівнях: 1) двосторонній формат/внутрішньоєвропейський; 2) багатосторонній фрормат Ради СС; 3) партнерський фрормат - здатність ЄС налагоджувати й розвивати дипломатичні відносини з третіми країнами (рис. 1).
Процес оновлення функцій трансорормаційних посольств усередині ЄС відбувається не повсюдно, до того ж з різною інтенсивністю. Але сам фракт членства в СС є перешкодою для військових намірів між країнами-членами, i тому одне із завдань дипломатії — гарантія національної безпеки від загроз інших країн у цьому державному середовищі - має другорядне значення в міжєвропейській дипломатії. Разом з тим зростає увага до інтерпретацій політичних меседжів країн-членів і акумуляції сил дипломатії на службу фрормування «бренду ЄС» $з$ метою формування переконливого лідерства у багатьох сорерах діяльності.

3 огляду на це, стимулюється розвиток нових галузей дипломатії у розрізі вже фрункціонуючих видів: економічної, комерційної, екологічної, енергетичної, кліматичної, медійної тощо. Новочасний вектор дипломатії спрямовано на підвищення рівня ефективності використання колективних ресурсів на основі інформаційних та інноваційних технологій. Формування іміджу ЄС та його дипломатичної служби обумовлено зміною характеру зовнішніх зносин на фоні багатополярної системи міжнародних економічних відносин, необхідністю створення більш скоординованого і дієвого механізму співробітництва держав ЄС з іншими країнами та регіонами для упередження чи реагування на глобальні виклики (у т.ч. екологічного характеру), а також загроз європейській і світовій безпеці.

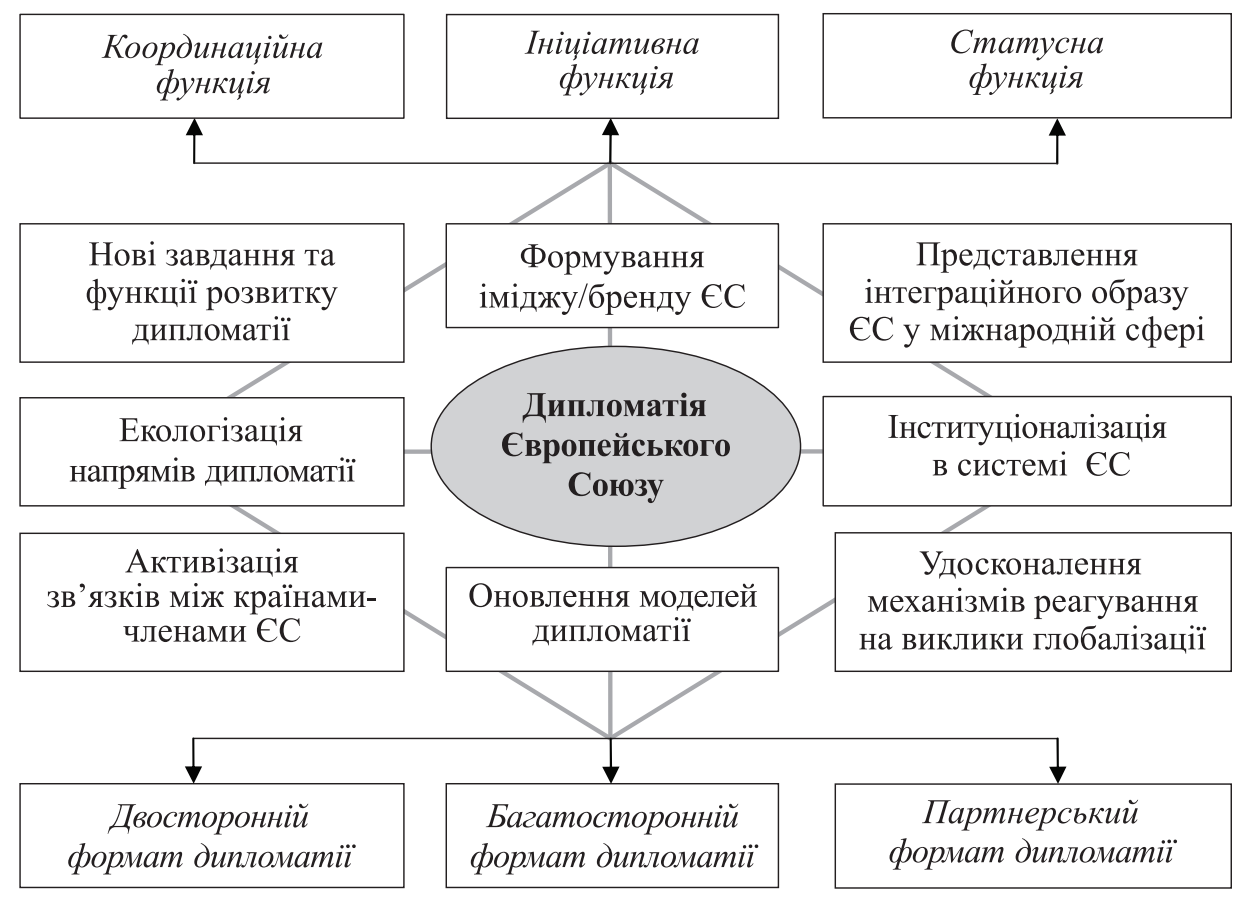

Рис. 1. Міжнародна контурність дипломатї $Є$ Е * Джерело: розроблено автором. 
У положеннях основних документів про діяльність Європейської служби зовнішньої діяльності (ЄСЗД) акцентовано увагу на двох ключових фрункціях: ініціативній і координаційній. Але в оцінках і коментарях щодо перспектив розвитку ЄСЗД виокремлюються питання спроможності до стратегічного планування зовнішньої політики ЄС для покращення ефрективності її фрункціонування та зміцнення позицій в євроінтеграційній архітектурі. Також ЄСЗД має узгоджувати позиції різних гравців, які прагнуть зберегти і посилити свій вплив у євроінтеграційній спільноті. Водночас процес узгодження - це і прояв «статусних інтересів» країн-членів. Тому ССЗД доводиться виступати медіатором між країнами та інституціями в ході вироблення спільних позицій усередині ЄС і ї головним (але не єдиним) ретранслятором назовні - своєрідним «вузловим центром» внутрішньої та зовнішньої дипломатії СС [7].

Нині практика зовнішньої політики СС має значну динаміку, що спонукає міністрів, дипломатів, послів, консулів та інших представників дипломатичної служби використовувати інтерактивні технології для презентації офіційної позиції своєї країни та виважено підходити до формування їі позитивного образу/іміджу в засобах масової інформації, в соціальних та інших мережах. Зокрема, у рамках фрнкціонування проекту «The GREAT Britain campaign», бренд Великої Британії зміцнюється силами таких державних інституцій, як Міністерство закордонних справ і у справах Співдружності націй Великої Британії та Національним департаментом торгівлі та інвестицій.

Крім того, нині спостерігається швидке оновлення медійного контенту щодо: популяризації та брендингу країн, структурування аудиторії прихильників культури європейських країн, привернення уваги до різних проблем цих країн: економічних, соціальних, екологічних, демографічних тощо. На тлі збільшення екологічних проблем і масштабів природнотехногенних катаклізмів, посилення транскордонних загроз, конфліктів за енергетичні та водні ресурси, утворення соціально-економічних дисбалансів країни СС усвідомлюють складність глобальних питань, що постали не лише перед європейською спільнотою, але й перед людством.

3 огляду на це, у посилах дипломатії ЄС дедалі частіше озвучується необхідність співробітництва в екологічній сорері між країнами світу. Впродовж останніх десятиліть активізовано переговорний процес і міжнародний діалог на основі постійного удосконалення екологічного законодавства ЄС (до складу його входять понад 300 законодавчих актів: понад 20 регла- ментів, 70 директив; рішення, рекомендації, офіційні листи та інші політичні документи) [8]. Це забезпечило певну результативність і уможливило:

1) сорормувати певний «образ європейської спільноти», що прагне до високих екологічних стандартів у різних сорерах життєзабезпечення;

2) виокремити «екологічних бренд $\mathrm{CC}$ » у світі різними засобами, у т.ч. політичними, дипломатичними, інорормаційними, культурними;

3) розширити зону європейського впливу на інші країни через окреслену «екологічну місію»на основі міжнародної економічної інтеграції;

4) стимулювати розвиток секторів і кластерів екологічної дипломатії [9].

Прикладом цього слугує Мережа Європейського Союзу для імплементації та застосування права навколишнього природного середовища (IMPEL), діяльність якої передбачає координацію органів влади країн-членів з метою:

- створення необхідного стимулу в СС для забезпечення ефективнішої імплементації та застосування законодавства у сорері навколишнього природного середовища;

- обмін інформацією та досвідом, обговорення проблем та надання практичних порад щодо імплементації та застосування екологічного законодавства ЄC;

- досягнення оптимального рівня узгодженості в підході до імплементації та застосування екологічного законодавства ЄC;

- сприяння взаєморозумінню спільних характеристик і відмінностей у національних системах регулювання;

- розвиток ефрективної практики щодо інспекції, надання дозволів, моніторингу, звітування та застосування екологічного законодавства $\mathrm{CC}$.

Діяльність Європейської консультативної ради з навколишнього природного середовища об'єднує ради, створені європейськими урядами для надання незалежних, науково обгрунтованих порад із навколишнього природного середовища і сталого розвитку. Мережа є потужними засобом для обміну інформацією і досвідом у Європі з метою: покращення консультацій, які країни надають національним і регіональним урядам; використання досвіду та роботи рад в інших країнах; розгляд актуальних питань на європейському рівні; впливу на розробку екологічної політики на рівні ЄС.

Наприклад, результатом таких зусиль є також позиції країн-членів ЄС за Індексом екологічної ефективності (Environmental Per- 
formance Index - EPI) серед 180 країн світу за 24 показниками в розрізі десяти категорій проблем, які характеризують стан навколишнього природного середовища і життєспроможності екосистем. Кожна країна в цьому рейтингу має свою оцінку щодо її наближеності до встановлених цілей глобальної екологічної політики. Так, EPI - це карта прогресивних досягнень країн за екологічними показниками. Особливістю цього рейтингу $є$ те, що він розробляється спільно Єльським і Колумбійським університетами в партнерстві зі Всесвітнім економічним форумом. За результатами ЕPI-2018 країни СС посідають лідируючі позиції - 14 з найкращих 20 місць (табл. 1).

Вважаємо, що дипломатія в рамках потужної інтеграційної спільноти доволі успішно формує еко-брендинг і свідчить про еволюцію суспільних відносин. Координація співпраці між країнами-членами СС у цьому форматі орієнтується на взаємодію між різними політиками, експертами, дослідниками, вченими, бізнесменами, екологами, активістами. Динаміка інформаційного обміну має забезпечити: удосконалення екологічної політики з акцентом на міжнародну консолідацію; збалансування ресурсних можливостей і потреб суспільства; узгодження цілей торговельної, екологічної та безпекової політики країн; фрормування нових ринків збуту екологічної продукції та інвестування екологічно спрямованих проектів.

Зокрема, відкритість до міжнародного діалогу є одним із ключових напрямів співпраці України та ЄС у рамках Угоди про асоціацію між Україною і СС - це сорера охорони навколишнього природного середовища. В главі 6 . «Навколишнє середовище» цієї Угоди йдеться, що сторони розвивають і зміцнюють співробітництво з питань охорони навколишнього природного середовища й у такий спосіб сприяють реалізації довгострокових цілей стійкого розвитку і зеленої економіки.

Висновки. Посилення уваги дипломатії ЄС до питань екології в просторі міжнародної інтеграції, запровадження політичних новацій та проведення соціально-економічних трансформацій має забезпечити позитивні наслідки для всіх країн-членів ЄС. У майбутньому це сприятиме отриманню відповідних ефектів і переваг для України на основі розвитку стратегічного партнерства і торговельно-економічних відносин з країнами ЄС у сорері екологічної та природоохоронної діяльності. Активізація зусиль державних інституцій і представників дипломатичної системи щодо обміну зарубіжним досвідом впровадження механізмів еко-

таблиия 1

Позиції країн-членів СС у міжнародному рейтингу за Індексом екологічної ефективності (2018р.)

\begin{tabular}{|l|l|l|l|c|c|}
\hline \multicolumn{1}{|c|}{ країна } & \multicolumn{1}{|c|}{$\begin{array}{c}\text { Позиції } \\
\text { в рейтингу }\end{array}$} & $\begin{array}{c}\text { Індекс } \\
\text { резуьтативності } \\
\text { діяогічної } \\
\text { діянсті }\end{array}$ & $\begin{array}{c}\text { Позиції } \\
\text { в рейтину }\end{array}$ & $\begin{array}{c}\text { Індекс } \\
\text { реколотивності } \\
\text { діяльності }\end{array}$ \\
\hline \hline Франція & 2 & 83,95 & Греція & 22 & 73,60 \\
\hline Данія & 3 & 81,60 & Кіпр & 24 & 72,60 \\
\hline Мальта & 4 & 80,90 & Португалія & 26 & 71,91 \\
\hline Швеція & 5 & 80,51 & Словаччина & 28 & 70,60 \\
\hline Великобританія & 6 & 79,89 & Литва & 29 & 69,33 \\
\hline Люксембург & 7 & 79,12 & Болгарія & 30 & 67,85 \\
\hline Австрія & 8 & 78,97 & Чехія & 33 & 67,68 \\
\hline Ірландія & 9 & 78,77 & Словенія & 34 & 67,57 \\
\hline Фінляндія & 10 & 78,64 & Латвія & 37 & 66,12 \\
\hline Іспанія & 12 & 78,39 & Хорватія & 41 & 65,45 \\
\hline Німеччина & 13 & 78,37 & Угорщина & 43 & 65,01 \\
\hline Бельгія & 15 & 77,38 & Румунія & 45 & 64,78 \\
\hline Італія & 16 & 76,96 & Естонія & 48 & 64,31 \\
\hline Нідерланди & 18 & 75,46 & Польща & 50 & 64,11 \\
\hline
\end{tabular}

Джерело: розроблено автором на основі [10]. 
брендування дедалі набуватиме значущості. Подальші наукові розвідки з окресленої проблематики можна розглядати в таких аспектах: екологічна безпека у системі фрормування брен- ду країни, національний бренд у фрорматі екологізації державно-приватного партнерства, екологічний потенціал українського бізнесу в контексті брендингу країни тощо.

\section{СПИСОК ВИКОРИСТАНИХ ДЖЕРЕЛ}

1. Кіслов Д. Брендинг як вид державних маркетингових комунікацій // Інвестиції: практика та досвід. 2015. № 1. С. $136-140$.

2. Циганкова Т., Завгородня Т. Глобальний бренд країни у сучасних технологіях торговельної маркетингової діяльності (2011) URL: http://iepjournal.com/journals/14-15/2011_2_Tsigankova.pdf

3. Полішко Г. Світовий досвід створення національних брендів // Бізнесінформ. 2015. № 11. C. 80-85.

4. Akker D. Creation of an Umbrella Nation Branding // Doctoral Dissertations. Twente. 2011. URL: http://essay.utwente.nl/61495/1/MSc_D_van_den_Akker.pdf

5. Anholt S. Nation «Branding»: Propaganda or Statecraft? // Public Diplomacy. Issue.2. 2009. P. 88-90. URL: http://publicdiplomacymagazine.com/wp-content/uploads/2010/01/summer_2009.pdf

6. Fan Y. Branding The Nation: Towards A Better Understanding // Place Branding and Public Diplomacy. Vol. 6. 2010. P. 97-103. URL: https://www.academia.edu/5185202/Branding_the_nation_towards_a_better_understanding

7. Ціватий В., Шаповалова О. Дипломатія та Європейська служба зовнішньої діяльності (ЄСЗД): політико-інституційний аспект // Зовнішні справи. 2013. №3. С. 42-45.

8. Мороз О., Ковальчук С. Теорія європейського еколого-економічного розвитку: Вінниця: ПП «ТД «Едельвейс і К», 2014. С. 287.

9. Бохан А.В. Екологічна дипломатія в інтерактивній модальності глобалізації: монографія. К.: Кив. нац. торг.-екон. ун-т, 2018. 465 с.

10. Environmental Performance Index. URL: https://epi.envirocenter.yale.edu/epi-countries

\section{Індормація про автора}

Бохан Аліна Василівна - кандидат економічних наук, доцент, доцент кафедри міжнародних економічних відносин, Київський національний торговельно-економічний університет (Україна, 02156, м. Київ, вул. Кіото, 19; e-mail: alina.bokhan@i.ua).

A.V. Bokhan

Ph.D in Economics, Associate Professor

Department of International Economic Relations Kyiv National University of Trade and Economics

(Ukraine, Kyiv; e-mail: alina.bokhan@i.ua)

\section{DIPLOMACY OF THE EUROPEAN UNION AND ECO-BRANDING COUNTRIES}

The article deals with the issues of the development of the diplomacy of the European Union and its role in international integration and the formation of eco-branding of the countries. The main factors of activation of diplomatic activity in the conditions of globalization and exacerbation of environmental problems are determined. An urgent issue is the formation of a new image EU and the establishment of environmental imperatives in international economic, business and cultural communications. The synchronization of the actions of the countries in this area involves the achievement of the goals of development under the project of international cooperation "The 2030 Agenda for Sustainable Development». The results of countries in achieving goals affect their international image in the world.

In conditions of increasing competition, the perception of the EU is formed on the basis of active diplomacy of politicians, diplomats, entrepreneurs. Intercultural communication stimulates international dialogue and mutual understanding. Diplomatic initiatives in the formation of branding of the country are aimed at: effective relations with other countries (economic, business, commercial, trade); use of «soft power" of influence through cultural, religious, tourist, recreational, ecological and other attractiveness; the formation of favorable conditions for interaction between different countries (international business, investment climate, innovation network); representation of national products in world markets (brand name, corporate brand, branded brand); personal brand (president, politician, diplomat, businessman) to ensure constructive dialogue, overheating, mediation.

The image of the EU and its diplomatic service is due to the nature of external relations against the backdrop of a multipolar system of international economic relations and the need to use collective resources. EU diplomacy as a powerful integration community successfully forms eco-branding. This should be 
ensured in the future: improvement of environmental policy; balance of resource opportunities and needs of society; harmonization of trade and environmental policy objectives of countries; the formation of new markets for environmental products and the investment of environmentally-directed projects. According to the Indicators of the Environmental Efficiency Index, the EU leaders: France, Denmark, Malta, Sweden, Great Britain, Austria, Ireland, Finland. In the future, the growth of international dialogue is one of the key areas of cooperation between Ukraine and the EU within the framework of the Association Agreement between Ukraine and the EU - this is the sphere of environmental protection.

Keywords: European diplomacy, eco-brand, international ecological policy, environmental diplomacy, globalization.

\section{REFERENCES}

1. Kislov, D. (2015). Brendynh yak vyd derzhavnykh marketynhovykh komunikatsii [Branding as a Form of Public Marketing Communications]. Investytsii: praktyka ta dosvid [Investments: Practice and Experience], 1. 136-140. (In Ukr.)

2. Tsigankova, T. \& Zavgorodnya, T. (2011). Hlobalnyi brend krainy u suchasnykh tekhnolohiiakh torhovelnoi marketynhovoi diialnosti [The global brand of the country in modern technologies of trade marketing activity]. [Electronic source]. URL: http://iepjournal.com/journals/14-15/2011_2_Tsigankova. pdf (In Ukr.)

3. Polyshko, G. (2015). Svitovyi dosvid stvorennia natsionalnykh brendiv [World experience in creating national brands]. BiznesInform [BusinessInform], 11. 80-85. (In Ukr.)

4. Akker, D. (2011). "Creation of an Umbrella Nation Branding Strategy», Doctoral Dissertations. [Electronic source]. URL: http://essay.utwente.nl/61495/1/MSc_D_van_den_Akker.pdf

5. Anholt, S. (2009). Nation «Branding»: Propaganda or Statecraft?». Public Diplomacy, 2nd ed, p. 88-90. [Electronic source]. URL: http://publicdiplomacymagazine.com/wp-content/uploads/2010/01/summer_2009.pdf

6. Fan, Y. (2010). «Branding The Nation: Towards A Better Understanding», Place Branding and Public Diplomacy, 6. 97-103. [Electronic source]. URL: https://www.academia.edu/5185202/Branding_the_nation_towards_a_better_understanding

7. Tsivatyi, V. \& Shapovalova, O. (2013). Dyplomatiia ta Yevropeiska sluzhba zovnishnoi diialnosti (IeSZD): polityko-instytutsiinyi aspekt [Diplomacy and European External Action Service (OSZD): political and institutional aspect]. Zovnishni spravy [External affairs], 3. 42-45. (In Ukr.)

8. Moroz, O. \& Kovalchuk, S. (2014). Teoriia yevropeiskoho ekoloho-ekonomichnoho rozvytku [Theory of European ecological and economic development]. Vinnytsya: PE «TD «Edelweiss and K». 287. (In Ukr.)

9. Bokhan, A. (2018). Ekolohichna dyplomatiia $v$ interaktyvnii modalnosti hlobalizatsii [Ecological diplomacy in the interactive modalities of globalization]. Kyiv: KNUTE. 465. (In Ukr.)

10. Environmental Performance Index. [Electronic source]. URL: https://epi.envirocenter.yale.edu/epicountries

\section{Author}

Bohan Alina Vasylivna - Ph.D. in Economics, Associate Professor, Associate Professor, Department of International Economic Relations, Kyiv National University of Trade and Economics (Ukraine, 02156, Kyiv, 19 Kioto St., e-mail: alina.bokhan@i.ua). 